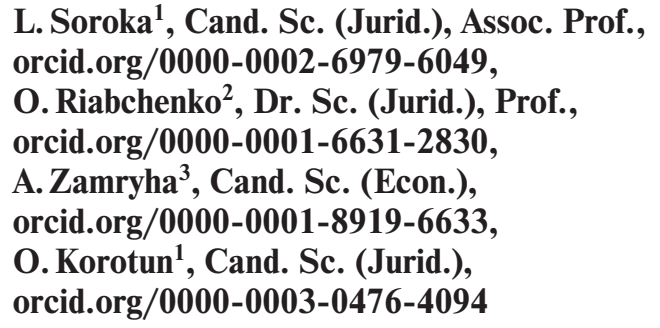

1 - Scientific Institute of Public Law, Kyiv, Ukraine, e-mail: lsoroka_kw@ukr.net

2 - University of the State Fiscal Service, Irpin, Ukraine, e-mail:80677171865@ukr.net

3 - Kyiv National Economic University named after Vadym Hetman, Kyiv, Ukraine, e-mail: artur.zamryha@kneu.edu.ua

\title{
STATE POLICY IN THE FIELD OF ENERGY EFFICIENCY
}

Purpose. To analyze the current situation in the field of energy efficiency, to study the problems of implementation of state policy in this area and the latest trends in the adoption of innovative tools and cost-effective ways to solve the problems of high energy prices, energy security and independence, air pollution and global climate change.

Methodology. The methodological basis for the study consists of both general scientific and special methods of scientific knowledge. Using the comparative legal method, an analysis of the norms of legislation of different countries of the world in the field of energy efficiency is carried out. The use of legal analysis and synthesis methods allowed formulating proposals for improving the current legislation that regulates the management of energy efficiency in Ukraine, as well as substantiating the main provisions for establishing interaction between the entities of energy efficiency management in Ukraine. Using the formally-logical method, the conceptual apparatus is investigated and the differences between the terms "energy efficiency" and "energy conservation" are distinguished. The method of generalization is used when studying and defining the main ways of improving the legislation that regulates the management of energy efficiency in Ukraine.

Findings. Systemic, planned implementation of the state policy, as well as financing and control over the use of funds provided for the implementation of energy efficiency programs will provide benefits in the following areas:

1. Environment: increasing efficiency can reduce greenhouse gas emissions and other pollutants and reduce water consumption.

2. Economy: energy efficiency is generally cheaper than investing in a new generation of "green" technologies. Energy efficiency can also stimulate the local economy and reduce the price pressure on gas.

3. Public utilities: energy efficiency can provide long-term profits by reducing the base load and reducing the need for additional energy interconnections.

4. Risk management: energy efficiency also diversifies utility portfolios and can be a means of protecting against uncertainty associated with fluctuations in fuel prices and other risk factors.

Originality. The experience of foreign countries in the field of energy efficiency policy analysis has been analyzed, and it has been found that in many cases, success in this field was achieved through the systematic policy of the state, system financing and consumer behavior change. The concept of "energy efficiency" and "energy saving" has been investigated, it has been proved that energy efficiency is an element of energy saving.

Practical value. The results of the study can be used by authorities when creating program documents and developing strategic plans in the field of energy efficiency.

Keywords: state policy, state administration, energy efficiency, energy saving, eurointegration

Introduction. Cost-effective energy efficiency programs have been successful in many countries since the late 1980s and have positive examples of energy savings. These programs have been successful in many different contexts: municipal, public administration; communal, public and private enterprise; gas or electricity. The funding options vary depending on the customer's program and goals. Developing joint efforts of the state strategy regarding compliance with norms and standards and innovation policy is a leading direction in promoting energy efficiency.

Energy efficiency is an area that has an impact on the sustainable development of any country and complements the national strategic goals such as reducing energy costs, securing energy supply, mitigating external energy dependence, moving to a low carbon economy and protecting the environment.

Energy efficiency is a win-win strategy for achieving public policy objectives in the terms of security of energy supply, climate change, competitiveness, trade balance, reducing investment in the growing energy needs of developing countries and solving problems of environmental pollution. In addition, by reducing energy consumption costs, countries reduce their vulnerability to price increases or supply disruptions, and improve their economic competitiveness of industry by reducing production costs.

The world is undergoing changes in approaches to the formation of energy policy of states: the transition from an out-

(c) Soroka L., Riabchenko O., Zamryha A., Korotun O., 2019 dated model of the energy sector, which was dominated by large producers, fossil fuels, inefficient networks, imperfect competition in the markets of natural gas, electricity, coal - to a new model, which creates a more competitive environment, equalizes opportunities for development and minimizes the dominance of one of the types of energy production or sources and/or ways of fuel supply. At the same time, preference is given to energy efficiency, energy saving and use of energy from renewable and alternative sources [1].

Comprehensive and sustained energy efficiency support is based on political will, motivated by understanding of the benefits of energy efficiency for society. Experts are concerned that energy efficiency issues have failed to attract sufficient attention to the highest political levels. Especially after the financial crisis which has led to the reduction of energy efficiency programs not only in Ukraine but also in many countries of the world.

And, as the authors of the "Professionalization of Energy Management in Ukraine" [2] pointed out rightly, there is a significant potential for energy efficiency in the whole world. But attempts to improve it are often not satisfied due to inadequate national political frameworks or lack of compliance with the relevant legislation. Among the shortcomings are policies that artificially lower the price of energy and thus contribute to wasteful consumption; subsidies for production and consumption that distort markets; poorly managed housing; and barriers to entry for new entrants. 
Literature review. Many scientists are engaged in the problems of effective public administration in the field of energy efficiency. Berg W, Nowak S, Kelly M, Vaidyanathan S, Shoemaker M, Chittum A. investigated the state system of energy efficiency indicators in their reports for 2016-2017 [3, 4]. Kaufman N, Palmer K.L. evaluated state energy efficiency programs in order to develop mechanisms for stimulating the introduction of advanced technologies and innovations [5]. Allcott H., Mullainathan S. provided a brief overview of the results of research on the behavior and application (both pilot and large-scale projects) of behavioral motivation as for energy [6]. In addition to foreign authors, the investigations of Ukrainian researchers were used in this work as well. Kyrychok O.S. and Shcherbak S. D. prepared and issued the training module "Basic Principles of State Policy in the Field of Energy Efficiency and Renewable Energy in Ukraine and in the World" within the framework of the project "Improving Energy Efficiency and Stimulating the Use of Renewable Energy in AgroFood and Other Small and Medium Enterprises (SMEs) of Ukraine". The project was implemented by the United Nations Industrial Development Organization (UNIDO) with the support of the Global Environment Facility (GEF). Zapaschuk L.V. investigated the energy saving as a way to increase the efficiency of production activities [7]. The prospects for the development of "green technologies" and their significance for the country's economy were considered by Soroka L. V. and Sytnichenko O. M. [8], Krichevsky S. V. [9, 10]. The issues of the activities of public administrations involved in the formation and implementation of state policy were analyzed by Zubko A. O. in his work [11], et al.

It should be noted that in the field of energy efficiency in most cases, the quantitative analysis of energy savings is studied by statistical comparison of cost-effective programs. The issues of policy development and implementation, the development of programs in the field of energy efficiency, both at the state level and at the regional level, have not been given enough attention. Study of potential for energy efficiency can be an effective tool to justify policy in the field of energy efficiency by making proposals in development of the detailed plans and programs.

In the article, the authors scorn the analysis of the state policy of foreign countries and Ukraine in order to develop an effective energy efficiency policy as one of the most constructive and cost-effective ways to solve the problems of high energy prices, energy security and independence, air pollution and global climate change.

Results. As the demand for energy increases, the way it is supplied changes. The use of renewable energy is gaining momentum, but the use of oil and gas also continues to grow, although their production and use become more efficient. The speed of change is accelerating day by day, so the energy industry needs developing projects in the long term, because today the industry is investing in projects, developments and systems that will exist for decades.

The Partnership and Cooperation Agreement between Ukraine and the European Union provides for the promotion of energy efficiency and energy conservation in conjunction with the development and support of renewable energy, which is an international obligation of Ukraine. In order to fulfill this obligation, Ukraine must use the principles operating in the EU and the advanced countries of the world. Therefore, the experience of foreign countries in formulating and implementing state policy in the field of efficient use of energy resources and renewable energy is very relevant.

Increasing energy supply prices, resource depletion and the need to bear environmental responsibility - all these require the development of new approaches to efficient energy management. Energy management is the use of technologies to improve energy performance. In order to be a fully energy independent state with efficient energy management, the country's leadership must develop and adopt strategic pro- gram documents for reforming the determined sector and obtaining the declared indicators in the future. Power management is often neglected, although there is considerable potential for energy savings and cost savings.

In addition to energy saving, reducing energy consumption can also save water (and vice versa). Construction strategies that improve the efficiency of water use reduce the need for both pumping and processing of water and the need for energy consumption for these functions. The use of water is also linked to electricity production. Water is used to cool generators of electricity, steam generation for power generation, and also to clean various types of fuel. Reducing demand for electricity will ultimately reduce water use.

Energy efficiency also plays a significant role in adapting to climate change by increasing resilience. Reducing energy consumption improves the overall reliability and sustainability of energy systems, as well as helping the population that relies on them. For example, if a large storm forces power plants to go offline (switch to stand-alone mode), it will lead to a sharp drop in power supply. However, countries that make extensive use of energy efficiency measures will have better opportunities to respond to this event, as they have already reduced their energy demand and therefore have infrastructure that will not be severely affected during the crisis.

Therefore, taking into account the given problems and the fact that recently the "big players" in the energy sector have been increasingly paying attention to this sphere, the study, which was conducted by British Petroleum Technology Outlook (BP) "The Potential of Technologies to Change the Ways of Production and Use of Energy by 2050" will be of great interest [12]. It covers three regions: China, Europe and North America, which together account for more than $50 \%$ of world primary energy consumption, but have very different energy systems. The project included a series of studies conducted by BP for three years with eight partners at universities and research institutes, using a combination of fundamental analysis and modeling of energy systems to get an idea of long-term trends.

The BP study is based on the analysis of about 130 energy technologies, including: oil and gas extraction, refineries and power plants; renewable energy sources such as wind and solar energy; vehicles from ordinary cars to electric cars and hybrids; thermal technologies from gas boilers to electric heat pumps; and accumulating energy from batteries to hydrogen. This report identifies five specific areas in which technology and system state policy can play a crucial role. And in the first place there is the field of energy efficiency.

In the scientific works, there is no consensus on the definition of the concept of "energy efficiency", so various approaches to its interpretation should be examined at first.

Both legal literature and normative legal acts of Ukraine pay attention to the concept of "energy saving" and not "energy efficiency". In foreign literature, by contrast, the term "energy efficiency" is used more often.

Energy efficiency is a branch of knowledge at the intersection of Engineering, Economics, Law and Sociology. This term means the rational use of energy resources, achievement of economically expedient efficiency of use of the existing energy resources at the actual level of development of equipment and technology, and observance of requirements to environment [13].

In "The Strategy on Energy Efficiency and Energy Saving at the Enterprises, Institutions, and Organizations Belonging to the Management of the State Agency of Ukraine for the Management of the Exclusion Zone, for the Period 20182020 ", energy efficiency is understood as a stable energy supply of objects, efficient (rational) use of energy resources, the use of less energy to provide the same level of energy supply of buildings, and structures or technological processes in the production. Energy efficiency is a criterion of quality for the functioning of the economic model of the state. Energy-saving 
(energy-efficient) measures are measures aimed at the introduction and production of energy-efficient products, technologies and equipment [1].

In the Law of Ukraine "On Energy Efficiency of Buildings" the term "energy efficiency" is not used, but the following concepts are used: economically feasible level - the level of energy efficiency of the building, at which the lowest costs (including operating and liquidation costs) are achieved during the normative terms of operation of the building (enclosing structures, engineering systems), taking into account the investment and income from energy generation (with the technical capability of the engineering system); energy efficiency of the building is a property of the building, characterized by the amount of energy required to create living conditions and/or life of people in such buildings [14].

As for the term "energy saving", it is defined in the framework Law of Ukraine "On Energy Saving", by which the legislator understands an activity (organizational, scientific, practical, information), which is aimed at the rational use and economical consumption of primary and converted energy and natural energy resources in the national economy, and which is implemented using technical, economic, and legal methods. And under the energy-saving policy they understand administrative, legal, financial and economic regulation of the processes of production, processing, transportation, storage, production, distribution and use of fuel and energy resources for the purpose of their rational use and economical expenditure [15].

Thus, energy saving involves various actions aimed primarily at changing the behavior of consumers, for example, to close the tap with water while brushing their teeth or install metering devices. Energy-efficient measures are primarily aimed at the use of innovative technologies in order to get a greater effect for the same amount of energy consumed. For example, replacement of ordinary incandescent light bulbs with economical ones, insulation of facades of buildings and so on. These measures, such as energy saving and energy efficiency, will ultimately lead to cost savings, reduced payments on utility bills and environmental protection. As a result, consumers and the state will benefit. Therefore, "energy saving" is a broader concept than "energy efficiency", which is a way of saving energy.

Implementation of energy efficiency programs almost always requires the creation of a special state body that is able to form the state policy in this area. Implementation of such measures as energy pricing or the implementation of international standards cannot be implemented without a specific executive body. In most countries, such an executive body is the Energy Efficiency Agency, which is increasingly recognized as a necessary tool for promoting energy efficiency policies. These institutions are usually government-funded from the state budget. In developing countries they are often supported by the foreign technical assistance funds.

Another important function of the Energy Efficiency Agencies is acting as a coordinator of all government initiatives in this area in order to avoid the uncoordinated actions of various ministries. In particular, the existence of such agencies has proved to be very useful in negotiating sectoral agreements with consumer groups, equipment manufacturers, to achieve specific goals for improving efficiency. In countries that receive financial assistance from the international development programs, such agencies can also act as a national partner with which investors can negotiate the implementation of financial packages for energy efficiency. Energy efficiency agencies also promote energy efficiency or act as a lobbyist for the long-term programs.

In Ukraine, the State Agency for Energy Efficiency and Energy Conservation (State Energy Efficiency) is the central executive body that implements state policy in the field of efficient use of fuel and energy resources, energy saving, renewable energy sources, and alternative fuels.

The main tasks of the State Department of Energy Efficiency are specified in the Regulation, approved by the Cabinet of Ministers of Ukraine from November 26, 2014, No. 676
[16]. In addition to the fact that the State Agency for the Development of Energy Efficiency is the body for the formulation and implementation of the state policy in the field of efficient use of fuel and energy resources, energy saving, renewable energy sources, and alternative fuels, it is entrusted with the tasks for the provision of administrative services in the relevant field.

The aim of the State Energy Efficiency activities is to develop, implement and evaluate programs and activities on energy efficiency; enter into agreements with stakeholders, companies, local authorities or non-governmental organizations; and, finally, to ensure coordination between higher and lower authorities (international, national, regional and local). For example, the State Agency for energy efficiency and energy saving of Ukraine signed contracts with the international companies of China (China Export Credit Insurance Corporation (SINOSURE)), Poland, Japan ("Mitsubishi Heavy Industries" LLC, and "Sumitomo" Corporation), etc. [17].

As it has been already mentioned above, energy saving issues are recognized today as one of the priorities of the country's energy policy. But despite the declared priorities of energy saving and energy efficiency, in the last decade, the reform of these areas was fragmentary. The use of energy resources, despite all attempts to reduce them, remains excessive. According to the international standards, at the level of state authorities, the implementation of organizational and technological solutions for energy efficiency remains rather low.

In spite of the problems that exist today in the energy efficiency sector, strategic program documents have been adopted that will help regulate the legal and regulatory support, both in the area of energy saving and renewable energy. The adoption of energy efficiency laws is a new approach to strengthening the institutional framework, although most laws have been adopted and implemented over the past 10 years. The adoption of just new laws is more effective because changing the existing law can be a complex process. Often these laws create a legal basis for the adoption of other by-laws, such as: labeling rules, standards for energy efficiency of buildings.

The main policy documents that have been adopted in recent decades and which form the state policy of Ukraine in the field of energy efficiency are:

1. Energy strategy of Ukraine for the period up to 2030 (approved by the Resolution of the Cabinet of Ministers of Ukraine dated March 15, 2006 No. 145-p. (expired)).

2. State Target Economic Program for Energy Efficiency and Development of Energy Sources for Renewable Energy Sources and Alternative Fuels for 2010-2020 (approved by the Resolution of the Cabinet of Ministers of Ukraine dated March 1, 2010 No. 243).

3. National Action Plan for Renewable Energy till 2020 (approved by the Resolution of the Cabinet of Ministers of Ukraine dated October 1, 2014 No. 902-r.).

4. The Strategy for Sustainable Development "Ukraine 2020" (approved by Decree of the President of Ukraine dated January 12, 2015, No. 5).

5. National Energy Efficiency Action Plan of Ukraine up to 2020 (approved by the Cabinet of Ministers of Ukraine dated November 25, 2015 No. 1228-r).

6. Energy strategy of Ukraine for the period up to 2035 "Safety, Energy Efficiency, Competitiveness" (approved by the Resolution of the Cabinet of Ministers of Ukraine dated August 18, 2017, No. 605).

7. Energy efficiency and energy saving strategy at enterprises, institutions and organizations belonging to the management of the State Agency of Ukraine for the management of the exclusion zone for the period 2018-2020 (approved by the Resolution of the State Agency of Ukraine for the management of the exclusion zone dated January 19, 2018, No. 4).

The analysis of the indicated program documents allowed allocating the following mechanisms for stimulating the development of energy efficiency in Ukraine: administrative, legal, economic, informational, technological. 
The administrative-legal mechanisms include: development and implementation of state and regional energy efficiency programs; international cooperation in order to develop the most effective ways of energy efficiency; drafting and adoption of normative legal acts in order to create conditions for national and foreign investments in the field of energy efficiency; reforming statistical reporting on energy consumption indicators; formation of a state system of monitoring and control over the efficient use of fuel and energy resources, production of energy from renewable sources of energy and alternative fuels, etc.

Economic mechanisms include the following: use of the "green" tariff; subsidies and state subsidies; tax and customs privileges (for example, companies that produce and consume electricity from renewable sources, are exempted from taxation of profits from their core activities, for enterprises using renewable energy - reduced land tax, exempt from VAT, value added tax and import duties on the import of certain types of renewable energy equipment into the customs territory of Ukraine, etc.). Economic incentives, directed to encouragement of investments into the energy efficient equipment, buildings, and processes, are implemented by decrease in investment expenditure, or directly (financial incentives), or indirectly (fiscal incentives).

At present, a controversial issue remains an attempt to solve the problems of utility payments by issuing state subsidies. Many energy-importing countries, that are not members of the Organization for Economic Co-operation and Development (OECD), protect their consumers from rising oil prices by supporting the subsidized price of some fuels. These subsidies represent a significant obstacle to investment in energy efficiency. In addition, they have a negative impact on state budgets, especially in recent years with the rise in oil prices. Subsidies often lead to abuse, leading to artificially high energy consumption in low-price countries and underestimation of consumption in higher-price countries. The first step of any energy efficiency policy should be adjustment of energy prices with the cost of energy supply so that consumers have incentives to change behavior or encourage them to purchase energy-efficient equipment and technologies.

The abolition of subsidies and the introduction of innovative mechanisms leads to more positive results. For example, large consumers with high energy consumption will be taxed; those who consume less will receive a discount. For each housing and each type of fuel they establish the consumption levels: in case of consumption below a basic indicator the bonus is provided (that is a discount), whereas it is necessary to pay a tax for consumption above the established indicator.

The information mechanisms primarily include conducting information campaigns aimed at changing consumer behavior and attitude to the problems and attitude of consumers to the problems of energy efficiency and energy saving; inclusion of relevant issues in the programs of educational institutions, the creation of regional centers of public awareness, etc. Public awareness is an important element in supporting energy efficiency and promoting energy efficiency policies and programs. Improvement of the sphere of energy efficiency and the market transformation connected with it demands informing consumers. As a rule, the majority of campaigns for informing the public and socially useful projects are developed and implemented by government agencies or public organizations.

The technological ones include: modernization of the gas transportation system, heat and water supply systems, thermal power plants and electric power plant; restructuring of enterprises aimed at reducing the material and energy intensity of production; the use of energy-efficient technologies and equipment, by attracting energy service companies, implementing projects using alternative energy sources, etc. But in order to be effective, labeling programs and work standards, as a way to stimulate technical progress and ensure sustainable energy efficiency, should be regularly reviewed and upgraded.
However, in practice, the process is delayed. Thus, national energy efficiency and renewable energy policies are aimed at modernizing and creating a new energy infrastructure, improving energy efficiency of production and consumption of fuel and energy resources, ensuring energy efficiency and promoting renewable energy.

In addition to the above mentioned program documents, a number of legislative acts aimed at resolving issues in the field of energy efficiency were also adopted:

1. The Law of Ukraine dated June, 22, 2017 "On the Energy Efficiency of Buildings" regulates the legal, socio-economic and organizational conditions for activities in the field of energy efficiency of buildings and aims at reducing energy consumption in buildings.

2. The Law of Ukraine "On the Energy Efficiency Fund" dated June, 8, 2017 - the formation of a financial base for support of energy efficiency initiatives, implementation of incentive measures and support for measures to improve the energy efficiency of buildings and energy saving (which complies with the provisions of the Resolution 2012/27/EU).

3. The Law of Ukraine dated June, 8, 2017 "On the Accession of Ukraine to the Statute of the International Agency for Renewable Energy Sources (IRENA)".

4. The Law of Ukraine dated June 9, 2018 "On Commercial Accounting for Thermal Energy and Water Supply" defines the bases of the organization of commercial accounting of heat energy consumption.

Thus, it can be argued that today the regulatory framework in the field of energy efficiency is well developed. The National legislation was adopted in the framework of agreements on the EU agreement, and regulates the following issues: economic, legal, social, environmental and technical conditions for energy efficiency, as for budgetary institutions, enterprises, organizations and citizens, promotion of energy saving, development of renewable energy and production of electricity from alternative sources.

Conclusions. The implementation of energy efficiency and energy saving reforms requires an appropriate level of investment activity. Developed countries reach this level under the following conditions:

1) availability of state guarantees (for example, guarantee of return of invested funds by investors);

2) the low level of corruption.

Today in Ukraine, both the first and the second condition cannot be guaranteed by the state [18]. In addition, it has been noted more than once that although reforms are being carried out, strategic programs are being adopted, but they are not systemic in nature, there is no effective monitoring and control over the implementation of these programs and plans by public administration bodies.

Positive foreign experience that Ukraine could use for successful implementation of energy efficiency reform:

Firstly, to develop the by-laws for the effective implementation of strategic programs timely. For example, the Energy strategy of Ukraine for the period up to 2035 "Safety, Energy Efficiency, Competitiveness" was approved in 2017, and the by-laws for its implementation have not been adopted yet as opposed to the EU countries, where this period does not exceed one year.

Secondly, for a successful European integration process, it is necessary not only to develop and adopt the by-laws on energy efficiency, but also to harmonize them with European technical standards and regulations. For example, in the $\mathrm{Na}$ tional action plan for energy efficiency of Ukraine till 2020, in 2015 it was noted that it was necessary to bring the regulatory framework in accordance with the requirements of European legislation in the field of energy labeling. As of May 2, 2019, only a few technical regulations were adopted, and only in 2017.

Thirdly, to reinforce the created institutional mechanisms by guaranteed financing, both state and non-state. 


\section{References.}

1. On Approval of the Strategy for Energy Efficiency and Energy Saving at the Enterprises, Institutions and Organizations Affiliated to the DACA Management Area for 2018-2020. Order of the State Agency of Ukraine for the Management of the Exclusion Zone (2018, January 19). Retrieved from https:// zakon.rada. gov.ua/rada/show/v0004767-18?lang=en.

2. Denysyuk, S. P., Kotsar, O. V., \& Chernetska, Yu. V. (2016). Energy efficiency of Ukraine. Best Project Ideas. Project "Professionalization and stabilization of energy management in Ukraine". Kyiv: Igor Sikorsky Kyiv Polytechnic Institute. Retrieved from http://io.iee.kpi.ua/sites/default/files/HANDBOOK_of_BEST_PRACTICES_2.pdf.

3. Berg, W., Nowak, S., Kelly, M., Vaidyanathan, S., Shoemaker, M., \& Chittum, A. (2016). The 2016 State Energy Efficiency Scorecard. American Council for an Energy-Efficient Economy. Report Number U1606. Washington D.C. Retrieved from https://aceee.org/research-report/u1606.

4. Berg, W., Nowak, S., Kelly, M., Vaidyanathan, S., Shoemaker, M., \& Chittum, A. (2017). The 2017 State Energy Efficiency Scorecard. American Council for an Energy-Efficient Economy. Report Number U1710. Washington D. C. Retrieved from https://aceee.org/research-report/u1710.

5. Kaufman, N., \& Palmer, K. L. (2012). Energy efficiency program evaluations: opportunities for learning and inputs to incentive mechanisms. Energy Effic [Internet], 5(2), 243-268. DOI: $10.1007 / \mathrm{s} 12053-011-9130-\mathrm{X}$.

6. Allcott, H., \& Mullainathan, S. (2010). Behavior and energy policy. Science, 327(5970), 1204-1205. DOI: 10.1126/science. 1180775 .

7. Zapashchuk, L. V. (2017). Energy conservation as direction of increasing efficiency of production. Economics and Society, 9, 428-434.

8. Soroka, L., \& Syntichenko, O. (2018). Sustainable Development of "Green" Technologies: the Legal Protection of Atmospheric Air from Polluting Substances. Advanced Space Law, 2, 70-75. DOI: 10.29202/asl/2018/2/9.

9. Krichevskiy, S. (2015). Evolution of Technologies, "Green" Development and Grounds of the General Theory of Technologies. Philosophy and Cosmology, (14), 119-138.

10. Krichevsky, S. (2017). Cosmic Humanity: Utopia, Realities, Prospects. Future Human Image, 7, 50-70.

11. Zubko, A. (2018). Administrative and Legal Status of Public Administration, which Carries out Administrative and Legal Regulation in Ukrainian Space Defense. $A d$ vanced Space Law, 1, 98-107. DOI: 10.29202/asl/2018/1/ 12.

12. BP Technology Outlook (2018). Retrieved from https:// www.bp.com/en/global/corporate/what-we-do/technologyat-bp/technology-outlook.html.

13. Zhovtyansky, V.A., Kulik, M. M., \& Stogniy, B.S. (Eds.) (2006). Energy Saving Strategy in Ukraine: Analytical and Reference Materials in 2 Volumes. Kyiv: Academiperidology.

14. On Energy Efficiency of Buildings (2017). The Law of Ukraine No. 2118-VIII (2017, June 22). Retrieved from https:// zakon.rada.gov.ua/laws/show/2118-19.

15. On Energy Conservation. The Law of Ukraine (2017, July 23). Retrieved from https://zakon.rada.gov.ua/laws/show/74/ 94-\%D0\%B2\%D1\%80.

16. On Approval of the Regulation on the State Agency for Energy Efficiency and Energy Conservation of Ukraine. Resolution of the Cabinet of Ministers of Ukraine, No. 676 (2014, November 26). Retrieved from https://zakon.rada.gov.ua/laws/show/6762014-\% D0 \% BF.

17. Interstate Consultants Engineers Guild (ICEG) (2018). Retrieved from http://iceg.com.ua/energoefektyvnist-ne-prosto-trend-a-vymoga-chasu/.

18. Bazaluk, O. (2016). Corruption in Ukraine: Rulers' Mentality and the Destiny of the Nation, Geophilosophy of Ukraine. Cambridge Scholars Publishing.

\section{Державна політика у сфері енергоефективності}

\author{
Л. В. Сорока ${ }^{1}$, О. П. Рябченко ${ }^{2}$, А. В. Замрига ${ }^{3}$, \\ O. М. Коротун ${ }^{1}$
}

1 - Науково-дослідний інститут публічного права, м. Київ, Україна, e-mail: lsoroka_kw@ukr.net

2 - Університет державної фіскальної служби України, м. Ірпінь, Україна, e-mail: 80677171865@ukr.net

3 - Київський національний економічний університет імені Вадима Гетьмана, м. Київ, Україна, е-mail: artur. zamryha@kneu.edu.ua

Мета. Проаналізувати існуючу ситуацію у сфері енергоефективності, дослідити проблеми реалізації державної політики в зазначеній сфері та останні тенденції у прийнятті інноваційних інструментів і економічно ефективних способів вирішення проблем високих цін на енергоносії, енергетичної безпеки й незалежності, забруднення повітря та глобальної зміни клімату.

Методика. Методологічну основу дослідження складають як загальнонаукові, так і спеціальні методи наукового пізнання. За допомогою порівняльно-правового методу здійснено аналіз норм законодавства різних країн світу у сфері енергоефективності. Використання методів правового аналізу й синтезу дозволили сформулювати пропозиції щодо вдосконалення чинного законодавства, що регулює порядок здійснення управління сферою енергоефективності в Україні, а також обгрунтувати основні положення щодо налагодження взаємодії суб'єктів управління сферою енергоефективності в Україні. За допомогою формально-логічного методу досліджено понятійний апарата та виокремлені відмінності термінів „енергоефективність“ і „енергозбереження“. Метод узагальнення застосовано при дослідженні й визначенні основних шляхів удосконалення законодавства, що регулює порядок управління сферою енергоефективності в Україні.

Результати. Системна, планомірна реалізація державної політики, а також фінансування й контроль за використанням коштів, наданих на реалізацію програм з енергоефективності, надасть переваги в наступних сферах:

1. Навколишнє середовище: підвищення ефективності може знизити викиди парникових газів та інших забруднюючих речовин, а також знизити споживання води.

2. Економічна: підвищення енергоефективності, як правило, дешевше, ніж інвестування в нове покоління „зелених“ технологій. Енергоефективність також може стимулювати місцеву економіку та знижувати ціновий тиск за використання газу.

3. Комунальні послуги: енергоефективність може забезпечити довгострокові прибутки за рахунок зниження базового навантаження та зменшення потреби в додаткових енергокомунікаціях.

4. Управління ризиками: енергоефективність також диверсифікує портфелі комунальних ресурсів і може бути засобом захисту від невизначеності, пов'язаної з коливаннями цін на паливо та іншими факторами ризику.

Наукова новизна. Проаналізовано досвід зарубіжних країн у сфері розробки політики з енергоефективності, з'ясовано, що в багатьох випадках успіх у зазначеній сфері досягався шляхом планомірної політики держави, системного фінансування та зміни поведінки споживачів. Досліджено поняття „енергоефективність“ та „енергозбереження“, доведено, що енергоефективність $€$ елементом енергозбереження.

Практична значимість. Результати дослідження можуть бути використані органами влади при створенні програмних документів і розробки стратегічних планів у сфері енергоефективності. 
Ключові слова: державна політика, державне управління, енергоефективність, енергозбереження, євроінтеграція

\section{Государственная политика в сфере энергоэффективности}

\section{Л. В. Сорока ${ }^{1}$, Е. П. Рябченко ${ }^{2}$, А. В. Замрыга ${ }^{3}$, E. H. Коротун ${ }^{1}$}

1 - Научно-исследовательский институт публичного права, г. Киев, Украина, e-mail: 1soroka_kw@ukr.net

2 - Университет государственной фискальной службы Украины, г. Ирпень, Украина, e-mail: 80677171865@ukr.net 3 - Киевский национальный экономический университет имени Вадима Гетьмана, г. Киев, Украина, e-mail: artur.zamryha@kneu.edu.ua

Цель. Проанализировать существующую ситуацию в сфере энергоэффективности, исследовать проблемы реализации государственной политики в указанной сфере и последние тенденции в принятии инновационных инструментов и экономически эффективных способов решения проблем высоких цен на энергоносители, энергетической безопасности и независимости, загрязнения воздуха и глобального изменения климата.

Методика. Методологическую основу исследования составляют как общенаучные, так и специальные методы научного познания. С помощью сравнительно-правового метода осушествлен анализ норм законодательства различных стран мира в сфере энергоэффективности. Использование методов правового анализа и синтеза позволили сформулировать предложения по совершенствованию действующего законодательства, регулирующего порядок осуществления управления сферой энергоэффективности в Украине, а также обосновать основные положения по налаживанию взаимодействия субъектов управления сферой энергоэффективности в Украине. С помощью формально-логического метода исследован понятийный аппарат и выделены различия терминов „энергоэффективность“ и „энергосбережение“. Метод обобщения применен при исследовании и определении основных путей совершенствования законода- тельства, регулирующего порядок управления сферой энергоэффективности в Украине.

Результаты. Системная, планомерная реализация государственной политики, а также финансирование и контроль за использованием средств, выделенных на реализацию программ по энергоэффективности, предоставит преимущества в следующих сферах:

1. Окружающая среда: повышение эффективности может снизить выбросы парниковых газов и других загрязняющих вешеств, а также снизить потребление воды.

2. Экономическая: повышение энергоэффективности, как правило, дешевле, чем инвестирование в новое поколение „зеленых“ технологий. Энергоэффективность также может стимулировать местную экономику и снижать ценовое давление за использование газа.

3. Коммунальные услуги: энергоэффективность может обеспечить долгосрочные прибыли за счет снижения базовой нагрузки и уменьшения потребности в дополнительных энергокоммуникациях.

4. Управление рисками: энергоэффективность также диверсифицирует портфели коммунальных ресурсов и может быть средством защиты от неопределенности, связанной с колебаниями цен на топливо и другими факторами риска.

Научная новизна. Проанализирован опыт зарубежных стран в сфере выработки политики по энергоэффективности, установлено, что во многих случаях успех в указанной сфере достигался путем планомерной политики государства, системного финансирования и изменения поведения потребителей. Исследовано понятие „энергоэффективность“ и „энергосбережение“, доказано, что энергоэффективность является элементом энергосбережения.

Практическая значимость. Результаты исследования могут быть использованы органами власти при создании программных документов и выработки стратегических планов в сфере энергоэффективности.

Ключевые слова: государственная политика, государственное управление, энергоэффективность, энергосбережение, евроинтеграция

Рекомендовано до публікації докт. юрид. наук В. В. Мушенком. Дата надходження рукопису 14.10.18. 